\title{
DÉTERMINATION DU MOMENT DE L'GSTRUS ET CONFIRMATION DE L'ÉTAT DE GRAVIDITÉ CHEZ LA TRUIE
}

\author{
C. MAIRE, Y. MAURY et F. POLINE

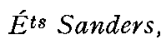 \\ 17, Quai de l'Industrie, \\ 91260 Juvisy sur Orge \\ RÉSUMÉ
}

La détermination du moment de l'œestrus par mesure du $\mathrm{pH}$ vaginal chez la truie s'est montrée précise et sûre. Son application dans la pratique semble cependant difficile en raison de la multiplication des mesures à effectuer sur chaque truie et de la complexité du matériel à utiliser.

La comparaison entre la méthode de diagnostic de gestation par biopsie vaginale et par injection d'un complexe d'œnan thate de testostérone et de valérianate d'œstradiol a donné des résultats voisins : 89,47 p. Ioo de diagnostics exacts contre 93,33 p. Ioo. La méthode par injection d'un complexe hormonal semble préférable en raison de sa simplicité.

\section{SUMMARY}

DETERMINATION OF OESTRUS AND PREGNANCY DIAGNOSIS IN THE SOW

Determination of the cestrus period by measurement of vaginal $\mathrm{pH}$ of the sow appears to be a precise and dependable method. Its practical use, however, is difficult, because of the numerous measurements to be done on each sow as well as the complexity of the apparatus.

Comparison between the method of pregnancy diagnosis by vaginal biopsy and by injection of a complex of testosterone-oænanthate and œstradiol-valerianate gave similar results : 89,47 p. Ioo and 93,33 p. Ioo respectively of right diagnosis. The method by injection of a hormonal complex seems preferable on account of its simplicity. 